\title{
Penerapan Pembelajaran Kooperatif Model Number Heads Together (NHT) dalam Meningkatkan Prestasi Belajar Siswa Mata Pelajaran Geografi Kelas X-IIS-1 di SMAN 1 Praya Timur Lombok Tengah Tahun 2016/2017
}

\author{
Kabul Ryadi \\ Guru SMAN 1 Praya Timur, kabulryadi@gmail.com
}

\section{INFO ARTIKEL}

Riwayat Artikel:

Diterima: 15-02-2018

Disetujui: 17-03-2018

\section{Kata Kunci:}

Number Heads Together Prestasi Belajar

\section{A. LATAR BELAKANG}

Perkembangan model pembelajaran dari waktu kewaktu terus mengalami perubahan. Model-model pembelajaran tradisional kini mulai ditinggalkan berganti dengan model yang lebih modern dan menyenangkan. Sejalan dengan pendekatan konstruktivisme dalam pembelajaran, salah satu model pembelajaran yang kini banyak mendapat respon adalah model pembelajaran kooperatif atau cooperative learning. Secara sederhana kata "cooperative" berarti mengerjakan sesuatu secara bersama-sama dengan saling membantu satu sama lainnya sebagai satu tim. Jadi, cooperative learning dapat diartikan belajar bersama-sama, saling membantu antara satu dengan yang lain dalam belajar dan memastikan bahwa setiap orang dalam kelompok mencapai tujuan atau tugas yang telah ditentukan sebelumnya. Dengan demikian, dapat dipahami bahwa cooperative learning menyangkut tipe pengelompokan yang didalamnya siswa bekerja terarah pada tujuan belajar bersama dalam kelompok kecil yang umumnya terdiri dari 4-6 orang.

Cooperative learning menyediakan banyak contoh yang perlu dilakukan para siswa. Pertama, siswa terlibat dalam tingkah-laku mendefinisikan, menyaring, dan memperkuat sikap-sikap, kemampuan, dan tingkah laku tingkah laku partisipasi sosial. Kedua, respek pada orang lain, memperlakukan orang lain dengan penuh pertimbangan kemanusiaan, dan memberikan semangat penggunaan pemikiran rasional ketika mereka bekerja sama untuk mencapai tujuan bersama, Ketiga, berpartisipasi dalam tindakan-tindakan kompromi, negosiasi, kerjasama, consensus dan penataan aturan mayoritas ketika bekerjasama (Isjoni, 2009: 25).

Berdasarkan hasil observasi dan praktik dilapangan selaku guru mata pelajaran geografi di kelas X SMAN 1 Praya Timur Kabupaten Lombok Tengah dalam kegiatan evaluasi pembelajaran formatif semester genap tahun sebelumnya dan hasil koreksi terhadap kemampuan siswa kelas X (sepuluh) pada kompetensi dasar "dinamika 
atmosfer dan dampaknya terhadap kehidupan" masih rendah. Hal ini terbukti dengan masih sedikitnya jumlah siswa yang tuntas pada hasil formatif sebelum diremedial atau perbaikan (mencapai KKM 75) yakni baru 22 orang siswa sekitar $62,86 \%$ dari 35 orang, sisanya 13 orang siswa dinyatakan tidak tuntas sekitar 37,14\%.

Sehubungan dengan pernyataan di atas maka penulis ingin meneliti penerapan Pembelajaran Kooperatif Model Number Heads Together (NHT) dalam meningkatkan prestasi belajar siswa mata pelajaran geografi Kompetensi dasar dinamika atmosfer dan dampaknya terhadap kehidupan Kelas X-IIS-1 semester genap di SMAN 1 Praya Timur Kabupaten Lombok Tengah tahun pelajaran $2016 / 2017$.

\section{B. METODE PENELITIAN}

Penelitian ini dilakukan di lembaga pendidikan menengah tepatnya di SMAN 1 Praya Timur Kabupaten Lombok Tengah tepatnya Kelas X-IIS-1 semester genap tahun pelajaran 2016/2017.

Waktu pelaksanaan penelitian tindakan kelas ini dilaksanakan pada bulan Pebruari s.d. April 2017. Siklus I akan dilaksanakan pada hari Senin, 13 Pebruari 2017. Sedangkan siklus II akan dilaksanakan pada hari Senin, 6 Maret 2017,

\section{Prosedur Penelitian}

Untuk menjelaskan tentang rancangan penelitian, kiranya beberapa hal yang memerlukan penjelasan sebagaimana langkah awal penelitian tindakan kelas. Adapun tahapan pelaksanaan PTK ini meliputi 4 langkah pokok yaitu : perencanaan, implementasi, observasi, dan evaluasi serta refleksi. Untuk lebih jelasnya akan dideskripsikan sebagai berikut:

\section{a. Rancangan Penelitian}

Rancangan penelitian yang diterapkan adalah rancangan penelitian tindakan kelas. Secara garis besar terdapat empat tahapan yang lazim dilalui, yaitu (1) perencanaan, (2) pelaksanaan, (3) pengamatan dan evaluasi (4) refleksi.

\section{b. Pelaksanaan Tindakan}

Pada pelaksanaan tindakan ini, peneliti melakukan kegiatan pembelajaran dengan menerapakan rancangan pembelajaran yang sudah dirancang sebelumnya.

\section{c. Tahap Pengamatan atau Observasi}

Observasi adalah mengamati hasil atau dampak dari tindakan-tindakan yang dilakukan siswa dalam proses pembelajaran geografi tentang dinamika atmosfer dan dampaknya terhadap kehidupan dengan kehidupan dilingkungan sekitar. Observer (peneliti sendiri) menggunakan instrument observasi antara lain lembar observasi. Observasi dilakukan peneliti dengan bantuan guru mata pelajaran yang bersangkutan (guru kolaborator). Sasaran observasi meliputi aktivitas yang dilakukan selama proses pembelajaran berlangsung dan respon siswa terhadap tipe pembelajaran Number Heads Together (NHT).

\section{d. Refleksi}

Refleksi adalah tahapan yang menentukan, sebelum melangkah pada siklus berikutnya. Kajian secara utuh dan menyeluruh terhadap perencanaan, tindakan, yang dilakukan dan di dukung dengan data observasi yang akurat. Jika hasil tes tersebut belum memenuhi nilai target/nilai yang telah ditentukan minimal standar KKM mata pelajaran geografi yakni 75, akan dilakukan tindakan siklus II dan masalah-masalah yang timbul pada siklus I akan dicarikan alternatif pemecahannya pada siklus II, sedangkan kelebihan-kelebihannya akan dipertahankan dan ditingkatkan.

\section{Metode Pengumpulan Data}

a. Data aktivitas guru dalam kelas diambil menggunakan lembar observasi yang berbentuk (check list) pada setiap akhir siklus. (terlampir)

b. Data aktivitas siswa selama proses pembelajaran berlangsung diambil dengan menggunakan lembar observasi yang berupa "aktivity check list" pada setiap siklus. (terlampir)

c. Mengukur kemampuan memahami dinamika atmosfer dan dampaknya terhadap kehidupan serta mengukur pemahaman dengan menggunakan tes berbentuk isian.

d. Data hasil belajar diperoleh dengan menggunakan tes dalam bentuk isian yang telah disiapkan pada setiap akhir siklus.

\section{Instrumen Pengumpulan Data}

Suharsimi Arikunto (2010:136) mengungkapkan bahwa instrumen penelitian adalah alat atau fasilitas yang digunakan oleh peneliti dalam mengumpulkan data agar pekerjaannya lebih mudah dan hasilnya lebih baik, dalam arti lebih cermat, lengkap, sistematis sehingga lebih mudah diolah. Instrumen perlakuan yang peneliti gunakan dalam penelitian ini adalah Rencana Pelaksanaan Pembelajaran (RPP). Adapun instrument pelengkap yang peneliti gunakan adalah sebagai berikut:

a. Lembar Observasi Aktivitas Guru
b. Lembar Observasi Aktivitas Siswa

\section{Teknik Analisa Data}

\section{a. Data Hasil Observasi Aktivitas Guru}

Data tentang aktivitas guru dianalisis secara deskriptif kualitatif. Indikator tentang aktivitas guru yang diamati adalah sebanyak 5 indikator dan setiap indikator terdapat 3 deskriptor.

1) Menentukan skor aktivitas maksimal guru yang ideal 


\section{2) Menentukan Mean Ideal (MI) dan Standar Deviasi Ideal (SDI)}

Analisis data aktivitas guru menggunakan MI (Mean Ideal) dan SDI (Standar Devasi Ideal) dengan rumus:

MI $\quad=\frac{1}{2} \times($ skor maksimal + skor minimal $)$

SDI $=\frac{1}{6} \mathrm{x}($ skor $\max -$ skor $\min )$

Keterangan :

Mi : Mean Ideal

SDi : Standar Deviasi Ideal

b. Observasi Aktivitas Siswa

1) Mencari kemampuan Kelompok

$\rightarrow$ Kemampuan tinggi

a. Batas atas $=\mathrm{M}+1 \mathrm{SD}$

$\longrightarrow$ Kemampuan sedang

b. Batas bawah = M - $1 \mathrm{SD}$

$\longrightarrow$ Kemampuan rendah

2) Mencari Indeks Prestasi Kelompok dengan rumus

$$
\mathrm{IPK}=\frac{\mathrm{M}}{\mathrm{SMI}} \times 100
$$

3) Mencari nilai rata-rata (Mean) dengan rumus

$$
M=\frac{\sum f x}{N}
$$

4) Mencari Indeks Prestasi Kelompok dengan rumus

$$
\mathrm{IPK}=\frac{\mathrm{M}}{\mathrm{SMI}} \times 100
$$

Pedoman Penentuan Indeks Prestasi Kelompok (IPK)

$$
\begin{gathered}
\text { IPK } \geq 90 \quad \text { Sangat tinggi } \\
75 \leq \text { IPK }<89 \quad=\text { Tinggi } \\
55 \leq \text { IPK }<75 \quad=\text { Normal } \\
35 \leq \text { IPK }<55 \quad=\text { Sedang } \\
\text { IPK }<30=\text { Rendah }
\end{gathered}
$$

(Wayan Nurkancana; P.P.N. Sumartana, 1998:107)

\section{Indikator Keberhasilan}

Penelitian ini dikatakan berhasil jika terjadi peningkatan prestasi belajar siswa. Prestasi belajar siswa dikatakan meningkat apabila $\mathrm{KK} \geq 85 \%$, dan hasil belajar dikatakan meningkat apabila hasil belajar minimal berkatagori sedang.

\section{HASIL DAN PEMBAHASAN}

\section{Hasil Penelitian}

\section{a. Siklus I}

Kegiatan pembelajaran siklus I dilaksanakan pada tanggal, 13 Pebruari 2017. Dalam pertemuan tersebut dilaksanakan evaluasi untuk mengukur hasil belajar dengan sebelum Penerapan Model Pembelajaran Kooperatif dengan Tipe Number Heads Together (NHT).

\section{Observasi Aktivitas Guru}

Data aktivitas guru dalam melaksanakan kegiatan pembelajaran diperoleh dengan menggunakan lembar observasi aktivitas guru. Berdasarkan hasil observasi dapat dilihat total skor aktivitas guru pada siklus I sebesar 15, diperoleh dari jumlah skor pada setiap indikator. Berdasarkan kriteria aktivitas guru yang tercantum pada bab III maka aktivitas guru pada siklus I dapat dikategorikan baik, karena terletak pada interval 11 $\leq \mathrm{Ag}_{\mathrm{g}}<15$.

\section{Observasi Aktivitas Siswa}

Berdasarkan analisis hasil observasi aktivitas siswa dari tiap indikator yang ditetapkan terdapat dua indikator yang belum maksimal dilakukan oleh sebagian besar siswa yaitu interaksi siswa dengan guru dan partisipasi siswa dalam menyimpulkan hasil belajar.

Berdasarkan kriteria aktivitas siswa maka aktivitas siswa pada siklus I dapat dikategorikan aktif, karena terletak berada pada interval $41 \leq A_{s}<60$.

\section{Hasil Evaluasi Siklus I}

Evaluasi dilaksanakan untuk mengukur sejauh mana kemampuan siswa terhadap materi yang diajarkan sebelum menerapkan tipe Number Heads Together (NHT) Mata Pelajaran Geografi. Evaluasi pada siklus I dilaksanakan pada pertemuan pertama dideskripsikan sebagai berikut.

TABEL 1

REKAPITULASI HASIL EVALUASI SIKLUS I

\begin{tabular}{|l|l|}
\hline Jumlah siswa & 35 \\
\hline Skor Rata-rata Siklus I & 74,97 \\
\hline Skor tertinggi Siklus I & 87 \\
\hline Skor terendah Siklus I & 69 \\
\hline Jlh skor tertinggi + rendah (M) & 156 \\
\hline Jlh skor tertinggi - rendah (R) & 18 \\
\hline $\begin{array}{l}\text { Kreteria ketuntasan Minimal (KKM) } \\
\text { Siklus I }\end{array}$ & 75 \\
\hline -Jumlah siswa Tuntas Siklus I & 20 \\
\hline -Jumlah Siswa Tidak tuntas Siklus I & 15 \\
\hline Ketuntasan Klasikal & $57,14 \%$ \\
\hline
\end{tabular}


Berdasarkan hasil tabel evaluasi pembelajaran sebelum Penggunaan tipe Number Heads Together (NHT) Mata Pelajaran Geografi siswa kelas X-IIS-1 semester genap SMAN 1 Praya Timur Kabupaten Lombok Tengah tahun pelajaran 2016/2017 tentang dinamika atmosfer dan dampaknya terhadap kehidupan di atas, skor tertinggi yang didapat siswa adalah 87 dan skor terendah 69 sedangkan nilai rata-rata 74,97. Persentase ketuntasan klasikal yang diperoleh yaitu $57,14 \%$. Dari nilai rata-rata tersebut dapat dikatakan bahwa, kemampuan memahami atmosfer dan pengaruh terhadap kehidupan masih banyak yang belum mencapai standar ketuntasan maksimal 75. Selain itu, prosentasi ketuntasan belajar (klasikal) siswa juga belum mencapai standar yang telah ditetapkan oleh penulis yaitu 85\%. Dengan demikian perlu adanya perbaikan di siklus berikutnya.

Hasil pembelajaran dinamika atmosfer sebelum menerapkan tipe pembelajaran Number Heads Together (NHT) perlu diadakan perbaikan pola atau pembelajaran pada siklus II dan dapat digambarkan ketuntasannya dalam digaram sebagai berikut.

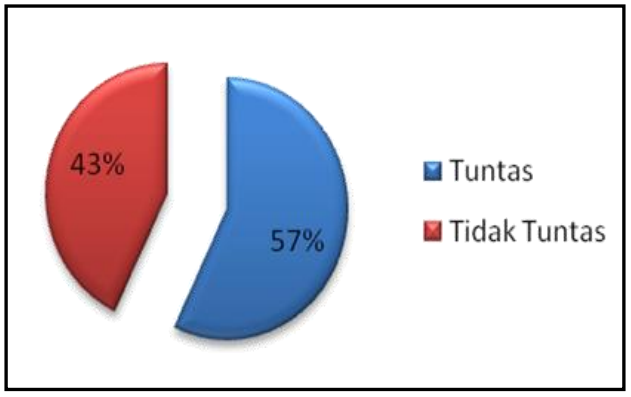

Gambar 1. Hasil Evaluasi Siklus 1

Diskripsi pembelajarannya adalah 16 orang siswa menyatakan sangat senang atau 45,71\%, dan 10 orang menyatakan senang atau 28,57\%, kemudian 9 orang menyatakan kurang senang $25,71 \%$.

\section{Mencari Kemampuan Individual}

Berdasarkan kriteria penelitian yang digunakan, maka selanjutnya dapat digunakan Standar Maksimal Ideal (SMI), Mean (M) dan Standar Deviasi Ideal (SDI), ketentuan klasikal. Adapun rumus untuk menentukan Standar Maksimal Ideal (SMI), Mean (M) dan Standar Deviasi Ideal (SDI) seperti yang tertera dalam Bab III. Dari rumus tersebut maka dapat ditentukan komponenkomponen tersebut sebagai berikut.

1. Menentukan SMI $=100$

2. Menentukan MI $=\frac{1}{2} \times($ ST-SR $)=\frac{1}{2} \times(87+69)=$ 78

3. Menentukan nilai $\mathrm{R}=\mathrm{ST}-\mathrm{SR}=87-69=18$

4. Menentukan SDI $=\frac{1}{6} \times \mathrm{R}=\frac{1}{6} \times 18=3,00$
Dari pola tersebut dapat diperoleh bahwa setiap siswa yang memperoleh skor 81,00 - 87 ke atas dinyatakan memiliki kemampaun tinggi, siswa yang memperoleh skor 75,00 s.d. 80,00 dinyatakan memiliki kemampuan sedang, dan siswa yang memperoleh skor < 75 ke bawah dinyatakan memiliki kemampuan rendah (data terlampir).

Berdasarkan kriteria dan data yang diperoleh dapat diketahui siswa yang memiliki kategori kemampuan tinggi, sedang dan rendah dapat diterjemahkan sebagai berikut.

1. Kemampuan siswa kategori tinggi :

5 orang $=14,29 \%$

2. Kemampuan siswa kategori sedang:

15 orang $=42,86 \%$

3. Kemampuan siswa kategori rendah: 15 orang $=42,86 \%$

\section{Mencari Kemampuan Kelompok}

Untuk mencari nilai kemampuan kemampuan kelompok dalam pembelajaran dinamika atmosfer dan dampaknya terhadap kehidupan sebelum menggunakan model pembelajaran (konvensional) pada siklus I di kelas X-IIS-1 semester genap SMAN 1 Praya Timur Lombok Tengah Tahun Pelajaran 2016/2017, dicari dengan menggunakan rumus.

$$
\begin{aligned}
& \sum \mathrm{fx} \\
& \mathrm{M}=\frac{{ }^{2}}{\mathrm{~N}}
\end{aligned}
$$

Berdasarkan data di atas, maka dapat ditentukan komponen-komponen yang diperlukan dalam menemukan kemampuan kelompok yaitu: jumlah keseluruhan nilai kemampuan belajar sebelum menerapkan pembelajaran kooperatif model Number Heads Together (NHT) sebagai berikut.

$$
\begin{aligned}
\sum \mathrm{fx} & =2625 \\
\mathrm{~N} & =35
\end{aligned}
$$

Selanjutnya memasukkan data kedalam rumus, yaitu

$$
M=\begin{array}{cc}
\sum \mathrm{fx} & 2625 \\
\mathrm{M} & 35
\end{array}=75,00
$$

Mencari Indeks Prestasi Kelompok (IPK)

$$
\begin{aligned}
& \text { IPK }=\underset{\text { SMI }}{\text { M }}
\end{aligned}
$$

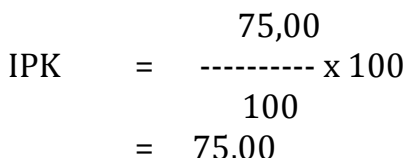

$$
\begin{aligned}
& =75,00
\end{aligned}
$$


Pedoman Penentuan Indeks Prestasi Kelompok (IPK)

$$
\begin{array}{ll}
\text { IPK } \geq 90 & =\text { Sangat tinggi } \\
75 \leq \mathrm{IPK}<89 & =\text { Tinggi } \\
55 \leq \mathrm{IPK}<75 & =\text { Normal } \\
35 \leq \mathrm{IPK}<55 & =\text { Sedang } \\
\text { IPK }<30 & =\text { Rendah }
\end{array}
$$

(Wayan Nurkancana; P.P.N. Sumartana, 1998:107)

Dari hasil analisis data di atas diketahui bahwa Indek Prestasi Kelompok (IPK) $=75,00$ ini menunjukkan bahwa kemampuan pembelajaran sebelum type number heads together (NHT) dalam meningkatkan prestasi belajar siswa mata pelajaran geografi kompetensi dasar dinamika atmosfer dan dampaknya terhadap kehidupan di kelas X-IIS-1 semester genap SMAN 1 Praya Timur Lombok Tengah Tahun Pelajaran 2016/2017, memiliki kemampuan normal.

\section{b. Siklus II}

Pelaksanaan pembelajaran pada siklus II Senin, 6 Maret 2017 dan hampir sama dengan siklus I, namun pada siklus II dilakukan perbaikan berdasarkan kekurangan yang ada pada siklus I terutama type atau model pembelajaran. Hal ini dilakukan agar aktivitas dan hasil belajar siswa pada kegiatan berikutnya memperoleh hasil yang lebih optimal.

Hasil observasi kegiatan guru dan kegiatan siswa dengan penerapan tipe Number Heads Together (NHT) Mata Pelajaran Geografi siswa kelas X-IIS-1 SMAN 1 Praya Timur Kabupaten Lombok Tengah tahun pelajaran 2016/2017 pada siklus II.

\section{Observasi Aktivitas Guru}

Data aktivitas guru dalam melaksanakan kegiatan pembelajaran diperoleh skor aktivitas guru pada siklus II sebesar 18 diperoleh dari jumlah skor pada setiap indikator. Berdasarkan kriteria aktivitas guru yang tercantum pada bab III maka aktivitas guru pada siklus II dapat dikategorikan sangat baik, karena terletak pada interval $16 \leq A_{g} \geq 20$.

Dengan penerapan type Number Heads Together (NHT) terlihat interaksi siswa sudah aktif. Guru berharap dengan adanya tipe Number Heads Together (NHT) ini dapat membantu peningkatan kemampuan siswa.

\section{Observasi Aktivitas Siswa}

Data aktivitas siswa dalam melaksanakan kegiatan pembelajaran skor aktivitas siswa pada siklus II sebesar 69 diperoleh dari jumlah skor pada setiap indikator. Berdasarkan kriteria aktivitas siswa yang tercantum pada bab III maka aktivitas siswa pada siklus II dapat dikategorikan sangat aktif, karena terletak berada pada interval $60 \leq A_{s}>80$.
Pada pelaksanaan siklus II, aktivitas siswa sudah mengalami peningkatan. Siswa melakukan aktivitas pembelajaran dengan sangat baik.

TABEL 2

REKAPITULASI HASIL EVALUASI SIKLUS II

\begin{tabular}{|l|l|}
\hline Jumlah Siswa & 35 \\
\hline Skor Rata-rata & 80,43 \\
\hline Skor tertinggi & 90 \\
\hline Skor terendah & 68 \\
\hline Jlh skor tertinggi + rendah (M) & 158 \\
\hline Jlh skor tertinggi - rendah (R) & 22 \\
\hline $\begin{array}{l}\text { Kreteria Ketuntasan Minimal (KKM) } \\
\text { Siklus II }\end{array}$ & 75 \\
\hline -Jumlah siswa Tuntas Siklus II & 33 \\
\hline -Jumlah Siswa Tidak tuntas Siklus II & 2 \\
\hline -Ketuntasan Klasikal Siklus II & $94,29 \%$ \\
\hline
\end{tabular}

Berdasarkan hasil tabel evaluasi siklus II tentang dinamika atmosfer dan dampaknya terhadap kehidupan (manfaat atmosfer) dengan menerapkan tipe Number Heads Together (NHT), dapat dikatakan bahwa siswa yang mencapai standar kemampuan pemahaman kategori tinggi berjumlah 12 orang siswa atau 34,29\%. Siswa yang memperoleh kemampuan pemahaman kategori sedang sebanyak 21 orang atau 60,00\% dan siswa yang memiliki kemampuan rendah adalah 2 orang atau 5,71\%. Sedangkan persentase ketuntasan klasikal yang diperoleh yaitu 94,29\%. Nilai tertinggi dalam siklus II adalah 90 dan nilai terendah adalah 68.

Dari nilai rata-rata tersebut dapat dikatakan bahwa, kemampuan pemahaman siswa pada materi atmosfer dan dampaknya terhadap kehidupan dengan menerapkan tipe Number Heads Together (NHT) memiliki presentasi ketuntasan belajar (klasikal) 94,29\% sudah mencapai standar yang telah ditetapkan oleh penulis yaitu 85\%, seperti diagram berikut.

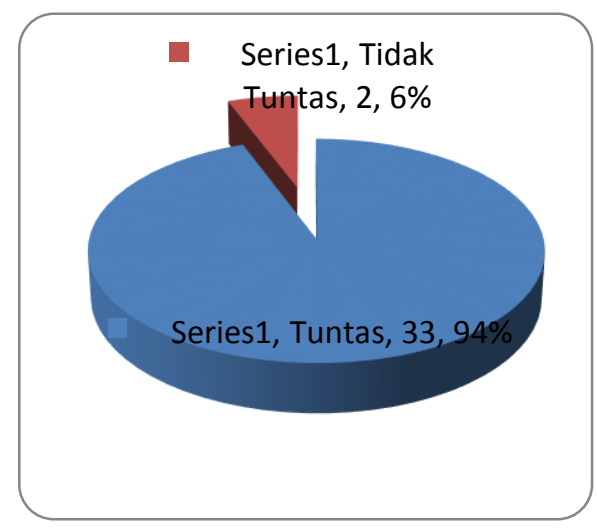

Gambar 2. Hasil Evaluasi Siklus 2 
Berdasarkan hasil jurnal siswa pada siklus II, diketahui bahwa dari 35 siswa, sebanyak 28 siswa atau $80,00 \%$ menyatakan sangat senang dan tertarik dengan pembelajaran tipe Number Heads Together (NHT) sebanyak 5 siswa atau $14,29 \%$ menyatakan senang. Sebanyak 2 siswa atau 5,71\% menyatakan kurang senang.

\section{Mencari Kemampuan Individual}

Berdasarkan kriteria penelitian yang digunakan, maka selanjutnya dapat digunakan Standar Maksimal Ideal (SMI), Mean (M) dan Standar Deviasi Ideal (SDI), ketentuan klasikal. Adapun rumus untuk menentukan Standar Maksimal Ideal (SMI), Mean (M) dan Standar Deviasi Ideal (SDI) seperti yang tertera dalam Bab III. Dari rumus tersebut maka dapat ditentukan komponen-komponen tersebut sebagai berikut.

$$
\begin{array}{ll}
\text { 1. Menentukan SMI } & =100 \\
\text { 2. Menentukan MI } & =\frac{1}{2} \times(\mathrm{ST}+\mathrm{SR})=\frac{1}{2} \times \\
& (90+68)=79 \\
\text { 3. Menentukan nilai R } & =\mathrm{ST}-\mathrm{SR}=90-68=22 \\
\text { 4. Menentukan SDI } & =\frac{1}{6} \times \mathrm{R}=\frac{1}{6} \times 27=3,67
\end{array}
$$

Berpedoman pada pola di atas maka dapat diterjemahkan bahwa setiap siswa yang memperoleh skor 82,67 - 90 ke atas dinyatakan memiliki kemampaun tinggi, siswa yang memperoleh skor 79,00 - 82,67 dinyatakan memiliki kemampuan sedang, dan siswa yang memperoleh skor < 75,33 ke bawah dinyatakan memiliki kemampuan rendah (data terlampir).

Berdasarkan kriteria dan data yang diperoleh dapat diketahui siswa yang memiliki kategori kemampuan tinggi, sedang dan rendah dapat diterjemahkan sebagai berikut.
1. Kemampuan tinggi
: 12 orang $=34,29 \%$
2. Kemampuan sedang
: 21 orang $=60,00 \%$
3. Kemampuan rendah
: 2 orang $=5,71 \%$

\section{Mencari Kemampuan Kelompok}

Untuk mencari nilai kemampuan kelompok mempelajari dinamika atmosfer dan dampaknya terhadap kehidupan di kelas X-IIS-1 semester genap SMAN 1 Praya Timur Lombok Tengah Tahun Pelajaran 2016/2017, dicari dengan menggunakan rumus.

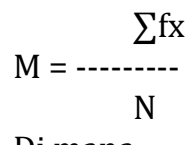

Di mana

$\mathrm{M} \quad=$ Kemampuan kelompok

$\sum \mathrm{fx} \quad=$ Skor keseluruhan

$\mathrm{N} \quad=$ Jumlah siswa (responden)
Berdasarkan data di atas, maka dapat ditentukan komponen-komponen yang diperlukan dalam menemukan kemampuan kelompok yaitu: jumlah keseluruhan nilai kemampuan belajar sebelum menggunakan pembelajaran kooperatif model number heads together sebagai berikut.

$$
\begin{array}{lll}
\sum \mathrm{fx} & = & 2815 \\
\mathrm{~N} & = & 35
\end{array}
$$

Selanjutnya memasukkan data kedalam rumus, yaitu

$$
\begin{array}{cc}
\sum \mathrm{fx} & 2815 \\
\mathrm{~N} & \mathrm{3}
\end{array}
$$

Mencari Indeks Prestasi Kelompok (IPK)

$$
\begin{aligned}
& \text { IPK = } \frac{\text { M }}{------x} 100 \\
& \text { IPK = } \frac{80,43}{-----\times 100} \\
& =80,43
\end{aligned}
$$

Pedoman Penentuan Indeks Prestasi Kelompok

$$
\begin{array}{lr}
\text { IPK } \geq 90 & =\text { Sangat tinggi } \\
75 \leq \mathrm{IPK}<89 & =\text { Tinggi } \\
55 \leq \mathrm{IPK}<75 & =\text { Normal } \\
35 \leq \mathrm{IPK}<55 & =\text { Sedang }
\end{array}
$$$$
\text { IPK }<30=\text { Rendah }
$$

Dari hasil analisis data siklus II di atas diketahui bahwa Indek Prestasi Kelompok (IPK) = 80,43 ini menunjukkan bahwa kemampuan pembelajaran kooperatif model number heads together (NHT) dalam meningkatkan prestasi belajar siswa mata pelajaran geografi kompetensi dasar dinamika atmosfer dan dampaknya terhadap kehidupan di kelas X-IIS-1 semester genap SMAN 1 Praya Timur Lombok Tengah Tahun Pelajaran 2016/2017, memiliki kemampuan tinggi.

\section{Pembahasan}

Penelitian ini dilaksanakan sesuai dengan prosedur PTK yang telah ditetapkan dari awal dengan perencanaan, pelaksanaan tindakan, observasi, dan evaluasi yang dilanjutkan dengan refleksi. Tahap perencanaan siklus I dan II yang dilakukan adalah menyiapkan rencana pembelajaran, lembar observasi untuk mencatat aktivitas guru dan siswa sebagai salah satu penentu indikator keberhasilan, pemahaman dinamika atmosfer dan dampaknya terhadap kehidupan sebagai penilaian sekaligus sebagai bahan evaluasi dan merencanakan hasil analisis.

Berdasarkan hasil analisis data pelaksanaan tindakan pada siklus I menunjukkan bahwa persentase ketuntasan klasikal kemampuan memahami dinamika atmosfer dan dampaknya 
terhadap kehidupan adalah $60 \%$.

Perubahan-perubahan yang dilakukan pada siklus II ini ternyata terbukti bisa merubah perolehan hasil belajar siswa, dengan ketercapaian persentase ketuntasan klasikal dari siklus I sebesar $57,14 \%$ meningkat menjadi $94,29 \%$ pada siklus II. Pencapaian ini sudah memenuhi target dari guru (peneliti) yang menetapkan standar ketuntasan yaitu 85\%. Sehingga penelitian ini berhenti di siklus II dan tidak dilanjutkan ke siklus selanjutnya dimana mengalami peningkatan sebesar 37,14\%.

Dengan demikian, penggunaan tipe Number Heads Together (NHT) dapat meningkatkan hasil belajar Mata Pelajaran Geografi siswa kelas X-IIS-1 SMA Negeri 1 Praya Timur Kabupaten Lombok Tengah tahun pelajaran 2016/2017.

Adapun perbedaan hasil siklus I dan siklus II meningkat dalam penerapan tipe Number Heads Together (NHT) di Kelas X-IIS-1 SMA Negeri 1 Praya Timur Kabupaten Lombok Tengah tahun pelajaran 2016/2017 disebabkan oleh beberapa faktor sebagai berikut :

1. Penerapan metode dan tipe pembelajaran pada siklus II lebih maksimal jika dibandingkan pada siklus I.

2. Konsentrasi belajar pada siklus II terlihat lebih menyenangkan daripada pada siklus I.

3. Antusiasme siswa pada siklus II lebih antusias jika dibandingka siklus I

\section{SIMPULAN DAN SARAN}

\section{Simpulan}

Berdasarkan hasil penelitian dan pembahasan hasil analisis data dapat ditarik simpulan bahwa tipe Number Heads Together (NHT) dapat meningkatkan hasil belajar Mata Pelajaran Geografi siswa kelas X-IIS1 SMA Negeri 1 Praya Timur Kabupaten Lombok Tengah tahun pelajaran 2016/2017. Peningkatan ini dapat dilihat dari ketuntasan klasikal yang diperoleh pada siklus I yaitu sebesar $57,14 \%$ dan siklus II meningkat menjadi $94,29 \%$ dengan peningkatan sebesar 37,14\%. Peningkatan ini dapat dilihat dari hasil observasi aktivitas guru sebesar 15 dengan kategori baik pada siklus I dan meningkat menjadi 18 dengan kategori sangat baik pada siklus II. Sedangkan aktivitas siswa pada siklus I sebesar 56 dengan katagori aktif, meningkat menjadi 69 dengan kategori sangat aktif pada siklus II.

\section{Saran}

a. Bagi siswa. Dalam proses belajar mengajar sebaiknya tetap melakukan interaksi atau kerjasama baik pada saat menyelesaikan permasalahan b. Bagi guru. Dalam proses belajar mengajar sebaiknya menggunakan beberapa seperti tipe Number Heads Together (NHT) agar senantiasa dapat meningkatkan hasil belajar.

c. Bagi sekolah. Penelitian ini dapat dijadikan acuan dalam pemecahan masalah yang berkaitan dengan upaya guru untuk meningkatkan kemampuan belajar siswa.

d. Bagi peneliti berikutnya. Peneliti yang ingin mengkaji tentang hal yang sama diharapkan untuk mengkaji secara lebih mendalam mengenai metode pembelajaran.

\section{UCAPAN TERIMA KASIH}

Dengan penuh rasa hormat, saya ucapkan teimakasih kepada:

1. Kepala Dinas Pendidikan yang telah memfasilitasi, mengizinkan penulis untk mengadakan penelitian hingga dapat terlaksana dengan baik.

2. Bapak Kepala sekolah yang selalu memberi dukungan sejak awal hingga terlaksananya penelitian ini dengan baik.

3. Guru-guru yang telah memberi dukungan baik secara moral maupun tindakan langsung dalam pelaksanaan penelitian ini.

\section{DAFTAR RUJUKAN}

Isjoni, 2009. Cooperative Learning. Alfabeta. Bandung.

Sanjaya, Wina, 2010. Strategi Pembelajaran Berorientasi Standar Proses Pendidikan. Prenada Media Grup. Jakarta.

Slameto. 2003. Belajar dan Faktor-faktor yang Mempengarufinya. Jakarta: Rineka Cipta.

Sudjana, Nana. 1995. Psikologi Pendidikan. Bandung: Cipta Karya

Suprijono, Agus, 2009. Cooperative Learning. Pustaka Pelajar. Yogyakarta.

Yamin, Martinis; Bansu I Ansari, 2009. Taktik Mengembangkan Kemampuan Individual Siswa. Gaung Persada Press. Jakarta.

Yasyin, Sulchan, 1997. Kamus Besar Bahasa Indonesia. Amanah. Surabaya.

Nurkencana,W,.dan Sunartana.1998. Evaluasi Hasil Belajar. Surabaya : Usaha Nasional 